\title{
A ADMISSIBILIDADE DOS EMBARGOS DE DIVERGÊNCIA
}

\author{
The admissibility of the motion for reconsideration due a split \\ decision
}

\section{Guilherme Pizzotti}

Mestrando em Direito Processual Civil pela Pontifícia Universidade Católica de São Paulo (PUC-SP). Graduação em Direito pela Pontifícia Universidade Católica de São Paulo (PUC-SP - São Paulo, SP, Brasil).

\section{Rodrigo Tannuri}

LL.M. pela Columbia University. Mestrando em Direito Civil pela Pontifícia Universidade Católica de São Paulo (PUC-SP - São Paulo, SP, Brasil). Graduação em Direito pela Universidade Candido Mendes (UCAM).

\section{Matheus Sanches}

Graduação em Direito pela Pontifícia Universidade Católica de São Paulo (PUC-SP - São Paulo, SP, Brasil).

\section{Resumo}

Este escrito se debruçará sobre o juízo de admissibilidade dos embargos de divergência à luz da Constituição Federal. A análise partirá de breves considerações sobre essa espécie recursal e de esclarecimentos acerca de sua íntima relação com o art. 926 do Código de Processo Civil, que prevê a necessidade de os tribunais uniformizarem sua jurisprudência, mantendo-a íntegra, estável e coerente. O estudo caminhará sobre as hipóteses de cabimento dos embargos de divergência, fazendo-se uma comparação entre o atual Código de Processo Civil e a legislação anterior, e depois discorrerá sobre os vetos promovidos pela Lei 12.256/2016. Ao final, far-se-á uma análise crítica aos vetos e suas consequências para a legislação processual civil brasileira.

Palavras-chave: Processo civil. Embargos de Divergência. Admissibilidade. Art. 926 do Código de Processo Civil. Lei $12.256 / 2016$.

\section{Abstract}

This article aims to discuss the admissibility of the motion for reconsideration due to a split decision and Brazilian Federal Constitution. The analysis starts with brief considerations about this appeal type and from clarifications about its intimate relationship with article 926 of the Brazilian Civil Procedure Code, which provides for the need for the courts to standardize their jurisprudence, keeping it integral, stable and consistent. The article also establishes a comparison between the current Civil Procedure Code and the previous legislation, and then discuss the vetoes promoted by Law 12.256/2016. In the end, a critical analysis will be made of the vetoes and their consequences for Brazilian civil procedural legislation.

Keywords: Brazilian Civil Procedure Code. Motion for reconsideration due to a split decision. Article 926. Law 12.256/2016.

\section{Sumário}

1. Introdução; 2. Os embargos de divergência e o novo Código de Processo Civil; 3. As hipóteses de cabimento; 4. Os vetos da Lei 13.256/2016; 5. Nota crítica aos vetos; 6 . Notas; Referências 


\section{INTRODUÇÃO}

O Código de Processo Civil, em seu art. 926, impôs aos tribunais a necessidade de se uniformizar sua jurisprudência, mantendo-a estável, íntegra e coerente. Conforme se discorrerá ao longo desse artigo, os embargos de divergência representam um mecanismo que prestigia essa diretriz, na medida em que têm como finalidade precípua erradicar entendimentos divergentes dentro dos órgãos fracionários no âmbito dos tribunais superiores. Portanto, por meio dos embargos de divergência se busca exatamente a uniformização e estabilidade da jurisprudência do Supremo Tribunal Federal e do Superior Tribunal de Justiça.

Para se realizar uma análise crítica ao juízo de admissibilidade dos embargos de divergência - objetivo deste artigo - é necessário, por óbvio, esclarecer quais são as atuais hipóteses de cabimento dessa espécie recursal, cotejando-se especialmente com as disposições da legislação processual civil anterior. A evolução histórica no ordenamento jurídico pátrio culminará numa análise crítica aos vetos que a Lei 13.256/2016 promoveu no art. 1.043 do Código de Processo Civil, oportunidade em que duas hipóteses de cabimento dos embargos de divergência foram expurgadas do sistema (no caso, os incisos II e IV desse dispositivo legal).

Tudo isso, ao final, para se concluir que a Lei 13.256/2016, especificamente no que diz respeito aos embargos de divergência, foi extremamente nociva e deletéria para o Código de Processo Civil e, por consequência lógica, ao próprio jurisdicionado.

\section{OS EMBARGOS DE DIVERGÊNCIA E O NOVO CÓDIGO DE PROCESSO CIVIL}

O Código de Processo Civil, como forma de salvaguardar os princípios da segurança jurídica e da isonomia, impõe aos Tribunais que uniformizem a sua jurisprudência, mantendo-a estável, íntegra e coerente. Esse não é apenas um comando encartado no seu art. $926,{ }^{1}$ mas uma diretriz a ser observada por toda a legislação processual civil. Por jurisprudência deve se entender uma coletânea de julgados, exarados por um tribunal, sobre determinada matéria, em um mesmo sentido. Portanto, na medida em que o art. 926 do Código de Processo Civil preza pela estabilidade e uniformização da jurisprudência dos tribunais, fica clara a existência de um comando explícito para que os magistrados deem igual tratamento para pessoas que se encontrem em idêntica situação jurídica, evitando-se uma imprevisibilidade das decisões judiciais. Respeitando-se a jurisprudência dos tribunais, valoriza-se a segurança jurídica, a celeridade do julgamento e o princípio da isonomia, para que jurisdicionados em situações iguais recebam tratamentos iguais, chegando-se ao mesmo resultado. ${ }^{2}$

Como ensina Alexandre Freitas Câmara, ${ }^{3}$ a exigência de estabilidade da jurisprudência indica que linhas de decisões constantes e uniformes a respeito de determinadas matérias não podem ser simplesmente abandonadas ou modificadas arbitrária ou discricionariamente. Não pode um órgão jurisdicional decidir uma matéria a cujo respeito exista jurisprudência constante simplesmente ignorando essa linha decisória, promovendo uma flutuação de entendimentos que contraria a exigência da segurança jurídica.

Imagine-se que o Superior Tribunal de Justiça tenha posicionamento consolidado no 
sentido de que determinada atividade não é sujeita à incidência de Imposto sobre Circulação de Mercadorias e Serviços - ICMS. Há, para os jurisdicionados, uma mensagem do Poder Judiciário de que caso queiram constituir pessoas jurídicas que imerjam nessa atividade terão a consciência tranquila de que o fisco não lhes imputará o pagamento dessa espécie tributária. O empresário, por exemplo, pode perfeitamente destinar o faturamento da empresa para o que bem lhe convier sem ter a preocupação de que uma parcela deveria ser segregada e vertida ao pagamento do ICMS. Dessa forma, é de suma relevância a estabilidade - que não se confunde com estanqueidade — do entendimento do Superior Tribunal de Justiça de que não haverá a incidência do tributo para essa atividade específica. Como já adiantado, a estabilidade, coerência e integridade da jurisprudência dos tribunais zelam para a isonomia entre os jurisdicionados, pois todos receberão o mesmo tratamento do Poder Judiciário, e prestigiam especialmente o princípio da segurança jurídica, uma vez que a rotineira volatilidade das decisões judiciais faz com que a população não compreenda sobre qual regra, ou sobre qual interpretação jurídica, está submetida.

Vicente Greco Filho ${ }^{4}$ ensina que os embargos de divergência são basilares para o combate a uma jurisprudência inconstante nos tribunais superiores, funcionam como um poderoso mecanismo de uniformização jurisprudencial, almejando a harmonia dos seus julgados. O intuito, nessa espécie recursal, deve ser promover uma só linguagem ou pensamento no seio desses Tribunais Superiores que, por sua vez, resultará no estabelecimento de uma jurisprudência mais consistente e pacífica, por meio de seus julgados e de suas súmulas, que se espraiarão por todos os demais Tribunais e juízes que constituem o Judiciário brasileiro.

De todo modo, importante ressaltar que o art. 926 do Código de Processo Civil não impede uma mudança na jurisprudência dos tribunais, o que provocaria um indesejável engessamento do direito. No entanto, a alteração do entendimento então uníssono da jurisprudência deve acontecer esporadicamente e desde que haja fundamentação adequada para tanto, como, por exemplo, a percepção de que houve significativas transformações na sociedade que justifiquem uma nova linha decisória nos tribunais. O sentido de estabilidade pretendido pela lei é o de que a jurisprudência uniforme não deverá ser alterada sem propósito. ${ }^{5}$

Feitos esses esclarecimentos iniciais, o Código de Processo Civil previu diversos mecanismos para a manutenção da uniformidade e estabilidade da jurisprudência dos tribunais. O dispositivo legal subsequente (art. 927) exemplifica alguns instrumentos, na medida em que se exige a observância, por parte dos juízes e tribunais, (a) das decisões do Supremo Tribunal Federal em controle concentrado de constitucionalidade (inciso I); (b) e dos enunciados de súmula vinculante (inciso II); (c) dos acórdãos em incidente de assunção de competência ou de resolução de demandas repetitivas e em julgamentos de recursos extraordinários e especial repetitivos (inciso III); (d) dos enunciados das súmulas do Supremo Tribunal Federal em matéria constitucional e do Superior Tribunal de Justiça em matéria infraconstitucional (inciso IV); e (e) da orientação do plenário ou do órgão especial aos quais estiverem vinculados (inciso $\mathrm{V}$ ).

Ao que interessa a esse trabalho, falemos dos embargos de divergência. Embora essa espécie de recurso, exclusiva dos tribunais superiores, não esteja elencada expressamente 
no art. 927 do Código de Processo Civil, é inegável que sua função precípua é justamente a de manter estável a jurisprudência do Superior Tribunal de Justiça e do Supremo Tribunal Federal, nos termos do art. 926 do Código de Processo Civil. Os embargos de divergência consistem em uma "técnica de concretização do dever de uniformidade prevista no caput do art. 926 do CPC" e possuem como objetivo "eliminar uma divergência intra muros, ou seja, afastar um conflito de entendimento na jurisprudência interna do tribunal superior."”

Regulamentados de forma sucinta nos arts. 1.043 e 1.044 do Código de Processo Civil, os embargos de divergência visam pacificar entendimentos dissonantes oriundos de órgãos fracionários internos ao mesmo tribunal superior. A legislação processual civil enxergou nos embargos de divergência uma forma de evitar que, por exemplo, a Terceira e a Quarta Turma do Superior Tribunal de Justiça externem posições inconciliáveis e contraditórias a respeito da mesma tese jurídica, relegando-se, nesse caso específico, para a Segunda Seção a tarefa de dizer qual entendimento deve ser privilegiado. Se ambos os posicionamentos são inconvivíveis, um há que ser reputado como correto e levado em consideração para orientar futuras decisões do Superior Tribunal de Justiça e também dos tribunais de segunda instância e demais magistrados.

A doutrina, aqui capitaneada pelos professores Teresa Arruda Alvim e Bruno Dantas, explica a razão de ser dos embargos de divergência, um recurso cuja função política é legitimar a atividade dos tribunais superiores. Considerando que compete ao Superior Tribunal de Justiça e ao Supremo Tribunal Federal dar a última palavra sobre, respectivamente, a interpretação da legislação federal e do texto constitucional, a existência de desarmonia interna na jurisprudência desses tribunais é sintoma de que eles não estão cumprindo adequadamente com as funções que Ihes foram atribuídas. Logo, "a única forma de reconduzir os Tribunais Superiores à sua razão de ser, quando a sua jurisprudência escancara o desacordo entre os componentes da corte, é admitir com amplitude os embargos de divergência."7

\section{AS HIPÓTESES DE CABIMENTO}

São duas as hipóteses de cabimento dos embargos de divergência, elencadas no art. 1.043 do Código de Processo Civil. De acordo com o texto legal, é embargável o acórdão de órgão fracionário que (a) em recurso extraordinário ou em recurso especial, divergir do julgamento de qualquer outro órgão do mesmo tribunal, sendo os acórdãos, embargado e paradigma, de mérito (inciso I); e (b) em recurso extraordinário ou em recurso especial, divergir do julgamento de qualquer outro órgão do mesmo tribunal, sendo um acórdão de mérito e outro que não tenha conhecido do recurso, embora tenha apreciado a controvérsia (inciso III).

Pela redação original do Código de Processo Civil, ainda era admissível a interposição de embargos de divergência contra acórdão de órgão fracionário que: (a) em recurso extraordinário ou em recurso especial, divergir do julgamento de qualquer outro órgão do mesmo tribunal, sendo os acórdãos, embargado e paradigma, relativos ao juízo de admissibilidade (inciso II); e (b) nos processos de competência originária, divergir do julgamento de qualquer outro órgão do mesmo tribunal (inciso IV). Os incisos II e IV do art. 1.043 do Código de Processo Civil, sobre os quais se debruçará adiante neste trabalho, foram revogados pela 
Lei $13.256 / 2016$.

De acordo com a doutrina, o inciso I do art. 1.042 do Código de Processo Civil:

\begin{abstract}
Trata de hipótese clássica de cabimento de embargos de divergência: o acórdão de órgão fracionário - turma ou seção — adota tese jurídica diferente da que adotou qualquer outro órgão do mesmo tribunal, inclusive o pleno, sendo ambos: acórdão embargado e divergente, relativos ao juízo de mérito. ${ }^{8}$
\end{abstract}

Sobre o inciso III do art. 1.043 do Código de Processo Civil, valem aqui maiores reflexões.

O Código de Processo Civil de 1973 previa ser embargável a decisão da turma que (a) em recurso especial, divergir do julgamento de outra turma, ou seção ou do órgão especial (inciso I do art. 546); ou (b) em recurso extraordinário, divergir do julgamento de outra turma ou do plenário (inciso II do art. 546). Veja-se, assim, que a legislação anterior pressupunha que o acórdão embargado tivesse julgado o mérito do recurso especial ou do recurso extraordinário.

Essa previsão legislativa, no entanto, contribuiu com certa instabilidade na jurisprudência do Superior Tribunal de Justiça à época da vigência do Código de Processo Civil de 1973. Em primeiro lugar, não raro o recurso especial era julgado, em seu mérito, no âmbito do agravo em recurso especial. Ou seja, os ministros conheciam o agravo para dar ou negar provimento ao recurso especial. À luz do art. 546, I do antigo Código de Processo Civil, nessa hipótese, poderia o acórdão do agravo em recurso especial ser considerado o "acórdão embargado" para viabilizar a interposição dos embargos de divergência?

Depois de certa controvérsia, a Corte Especial do Superior Tribunal de Justiça acertadamente pacificou o entendimento no sentido de admitir os embargos de divergência contra acórdão proferido em recurso especial e, excepcionalmente, contra acórdão exarado em sede de agravo em recurso especial, quando a decisão, fundamentada na autorização prevista no art. 544, $\S 4^{\circ}$, 'c', do CPC, conhece do agravo para dar provimento ao recurso especial. A contrário sensu, estabeleceu-se que se conhecido o agravo para, tão somente, negar seguimento ao recurso especial, não se admite a interposição de embargos de divergência, mormente porque não houve o enfrentamento do mérito da irresignação. ${ }^{9}$ Nesta segunda hipótese, incidiria o enunciado da Súmula 315 do Superior Tribunal de Justiça segundo o qual "não cabem embargos de divergência no âmbito do agravo de instrumento que não admite recurso especial".

Mas esse entendimento não resolvia o problema. Nos embargos de divergência 200.299/PE, por exemplo, - e aqui se traz apenas um dos vários julgados semelhantes do Superior Tribunal de Justiça - , constou na parte dispositiva do acórdão embargado que foi negado provimento ao agravo em recurso especial. A leitura da parte dispositiva do acórdão embargado, portanto, fazia pressupor que o mérito do recurso especial não tinha sido objeto de análise. Caso contrário, o correto seria constar que o agravo em recurso especial foi provido para se conhecer do recurso especial e a ele se negar provimento. Pela fundamentação do acórdão, no entanto, ficava claro que o Superior Tribunal de Justiça tinha de fato emitido juízo de valor sobre o mérito do recurso especial, embora, por uma atecnia, tenha feito constar em sua parte dispositiva o não provimento do agravo em recurso especial. Nesta 
situação, como ficaria a admissibilidade dos embargos de divergência?

A Primeira Seção do Superior Tribunal de Justiça, à época, entendeu corretamente pelo conhecimento dos embargos de divergência, pois, "em que pese no dispositivo da decisão monocrática mantida pelo acórdão embargado ter constado que foi negado provimento ao agravo em recurso especial manejado pela União, houve verdadeiro exame do mérito do recurso especial."10

Feito esse breve histórico da evolução da jurisprudência do Superior Tribunal de Justiça, o Código de Processo Civil enfim resolveu esse dilema, admitindo a interposição de embargos de divergência contra acórdão que, ainda que não tenha conhecido do recurso especial ou extraordinário, adentrou no mérito da controvérsia:

\footnotetext{
Sub judice: é embargável o acórdão de órgão fracionário que em recurso extraordinário ou em recurso especial, divergir do julgamento de qualquer outro órgão do mesmo tribunal, sendo um acórdão de mérito e outro que não tenha conhecido do recurso, embora tenha apreciado a controvérsia. (art. 1.043, III do Código de Processo Civil).
}

Portanto, já considerando a indevida confusão entre o juízo de admissibilidade e de mérito nos recursos excepcionais, o Código de Processo Civil previu a possibilidade de comparação entre acórdão que julga o mérito e acórdão de não admissão, mas no qual tenha sido apreciada a controvérsia. ${ }^{11}$

\section{OS VETOS DA LEI 13.256/2016}

A redação original do art. 1.043 do Código de Processo Civil previa como sendo embargável "o acórdão de órgão fracionário que, nos processos de competência originária, divergir do julgamento de qualquer outro órgão do mesmo tribunal" (inciso IV). Logo, um acórdão proferido em sede de ação rescisória no Superior Tribunal de Justiça, por exemplo, poderia ser objeto de embargos de divergência, desde que satisfeitos os demais requisitos legais.

Com a revogação desse dispositivo legal, no entanto, somente pode haver a interposição de embargos de divergência contra acórdão advindo de recurso especial ou extraordinário que, julgando o seu mérito, divergir do entendimento de qualquer outro órgão fracionário do mesmo tribunal:

Ainda que o parágrafo primeiro do art. 1.043 do Código de Processo Civil faça menção a ações de competência originária, ${ }^{12}$ essa expressão acabou se tornando inócua e obsoleta em razão da revogação do inciso IV do caput. Não há como se fazer uma interpretação extensiva ao $\S 1^{\circ}$ do art. 1.043 do Código de Processo Civil para permitir a interposição de embargos de divergência contra acórdão proveniente de ação rescisória no Superior Tribunal de Justiça uma vez que no rol taxativo das hipóteses autorizadoras da interposição desse recurso não consta mais processos de competência originária.

Por esses motivos, a despeito da previsão do parágrafo primeiro do art. 1.043 do Código de Processo Civil, a jurisprudência do Superior Tribunal de Justiça não vem admitindo um acórdão proveniente de processos de competência originária desse tribunal superior como sendo passível de embargos de divergência. É o que se verifica, exemplificativamente, 
do AgRg nos EAREsp 376.403/PI:

[...] sendo a finalidade dos embargos de divergência a uniformização da jurisprudência do Superior Tribunal de Justiça quanto ao direito federal, somente se admitem como paradigmas acórdãos proferidos em sede de recurso especial e de agravo em recurso especial que examinem o mérito da questão, não sendo aptos a tal finalidade os acórdãos proferidos em recurso ordinário em mandado de segurança, ação rescisória, habeas corpus e conflito de competência.

Parte da doutrina, no entanto, entende que por meio de uma interpretação extensiva do parágrafo primeiro do art. 1.043 do Código de Processo Civil poderia se concluir pela possibilidade de interposição de embargos de divergência contra acórdão advindo de processo de competência originária do tribunal superior. ${ }^{13}$ Outros doutrinadores, por outro lado, entendem que com a reforma da Lei 13.256/2016, os embargos de divergência passaram a se restringir sobre controvérsias sobre o mérito do recurso especial, impossibilitando que acórdãos advindos de processos de competência originária dos tribunais superiores viabilizem a sua interposição. ${ }^{14}$

Outro veto promovido pela Lei 13.256/2016 diz respeito ao inciso II do art. 1.043, que estabelecia a seguinte hipótese de cabimento dos embargos de divergência: "é embargável o acórdão fracionário que, em recurso extraordinário ou em recurso especial, divergir do julgamento de qualquer outro órgão do mesmo tribunal, sendo que os acórdãos, embargado e paradigma, relativos ao juízo de admissibilidade".

Em razão da revogação desse inciso III, não cabe mais a interposição de embargos de divergência quando a tese veiculada no acórdão paradigma versar sobre os requisitos de admissibilidade dos recursos especial e extraordinário.

A jurisprudência do Superior Tribunal de Justiça é consolidada no seguinte sentido:

[...] não cabem embargos de divergência com a finalidade de discutir eventual equívoco quanto ao exame dos requisitos de admissibilidade de recurso especial, tais como aqueles referentes à deficiência de fundamentação, ausência de prequestionamento, ao reexame de provas, à necessidade de interpretação de cláusulas contratuais. ${ }^{15}$

De igual modo, vale citar aqui o AgRg nos EAREsp 1419463/MG, Relator Ministro Sebastião Reis Júnior, julgado em 26 de junho de 2019, Corte Especial.

Parte da doutrina, contudo, diverge do entendimento predominante do Superior Tribunal de Justiça e defende a viabilidade da interposição de embargos de divergência quando a controvérsia entre teses jurídicas nos acórdãos paradigma e embargado se revelar no juízo de admissibilidade do recurso especial ou extraordinário. Essa interpretação guarda fundamento na previsão do art. 1.043, $\S 2^{\circ}$ do Código de Processo Civil, ao prescrever "que a divergência que autoriza a interposição de embargos de divergência pode verificar-se na aplicação do direito material ou do direito processual." De acordo, por exemplo, com os professores Teresa Arruda Alvim, Rogério Licastro Tores de Mello, Leonardo Ferres da Silva e Maria Lúcia Lins da Conceição, se o art. 1.043, $\$ 2^{\circ}$ do Código de Processo Civil permite que a divergência se verifique na aplicação do direito processual, por via interpretativa, deve se admitir que a divergência que disser respeito à admissibilidade do recurso especial e extraordinário (questão processual) possa ser objeto de embargos de divergência. ${ }^{16}$

Com a devida vênia, a interpretação mais correta do art. 1.043, §2 do Código de 
Processo Civil deve levar apenas à possibilidade de interposição dos embargos de divergência quando o mérito do recurso especial ou do extraordinário tiver sido julgado pelo acórdão embargado. Veja-se o seguinte exemplo: o acórdão embargado julgou o mérito do recurso especial e a ele deu provimento para consignar que o stay period (art. $6^{\circ}, \S 4^{\circ}$ da Lei $11.101 / 05)^{17}$ deve ser contado em dias corridos. Por outro lado, existe acórdão de outra Turma do Superior Tribunal de Justiça que deu provimento a outro recurso especial para determinar que essa mesma contagem de prazo aconteça em dias úteis. Tem-se aqui um perfeito exemplo de divergência de questão eminentemente processual, passível de embargos de divergência, em que o acórdão embargado julgou o mérito do recurso especial.

Ainda que não se concorde com o veto da Lei 13.256/2016 ao art. 1.043, II do Código de Processo Civil — algo com o que, conforme se explicará no capítulo subsequente, realmente não se concorda - , ele não pode ser desconsiderado. Se o legislador expressamente vetou a possibilidade de interposição de embargos de divergência para dirimir uma controvérsia situada na admissibilidade do recurso especial ou do recurso extraordinário, isso deve ser respeitado, ainda que se entenda ter havido uma opção equivocada quando da edição da Lei 13.256/2016.

\section{NOTA CRÍTICA AOS VETOS}

Os embargos de divergência, conforme se explicou ao longo desse trabalho, têm como finalidade precípua dirimir uma controvérsia interna no âmbito de órgãos fracionários do tribunal superior a respeito da mesma tese jurídica. Ao jurisdicionado é fundamental que os tribunais superiores uniformizem a sua jurisprudência, mantendo-a estável, íntegra e coerente, obedecendo, portanto, ao comando encartado no art. 926 do Código de Processo Civil.

Se a legislação processual civil preza pelos princípios da isonomia e da segurança jurídica - consequências diretas da uniformização da jurisprudência dos tribunais — por que então limitar as hipóteses de cabimento dos embargos de divergência? Se os embargos de divergência representam um mecanismo fundamental e de suma importância para erradicar controvérsias internas na jurisprudência do Supremo Tribunal Federal e do Superior Tribunal de Justiça, qual a justificativa razoável para que o legislador tenha suprimido do Código de Processo Civil os incisos II e IV do art. 1.043?

Com a devida vênia, mas não faz sentido, por exemplo, que a divergência de posicionamento em diferentes Turmas do Superior Tribunal de Justiça que diga respeito ao juízo de admissibilidade do recurso especial não possa ser objeto de embargos de divergência. Afinal, considerando que os embargos de divergência visam justamente à eliminação de entendimentos inconciliáveis dentro do Superior Tribunal de Justiça e do Supremo Tribunal Federal, a fim de que o "mais correto" sobreviva em detrimento do outro, qualquer espécie de divergência real e efetiva entre o acórdão embargado e o acórdão paradigma deveria aflorar essa espécie recursal. Impedir que conflitos jurisprudenciais envolvendo a admissibilidade dos recursos especial e extraordinário sejam objeto de embargos de divergência é circunstância que conspira contra a estabilidade, integridade e coerência da jurisprudência do Supremo Tribunal Federal e do Superior Tribunal de Justiça. ${ }^{18}$ 
Independentemente se o dissenso advier de acórdão que julgou o mérito do recurso especial, de acórdão que analisou os requisitos de admissibilidade do recurso especial, de acórdão proferido em sede de processo de competência originária do tribunal superior, não importa, em todas essas hipóteses haveria que se permitir a interposição dos embargos de divergência, pois somente assim estaria se prestigiando sem ressalvas o art. 926 do Código de Processo Civil.

Há questões cruciais envolvendo a admissibilidade dos recursos especial e extraordinário, objeto de constante divergência nos tribunais superiores, que merecem pacificação. Veja-se o exemplo do ERESp 831.326/SP. ${ }^{19}$ Discutia-se se o recorrente deve impugnar no agravo em recurso especial todos os fundamentos da decisão de inadmissão do recurso especial ou se, havendo fundamentos autônomos entre si, a insurgência em relação a apenas um deles poderia ensejar o conhecimento do agravo e do próprio recurso especial. Mais especificamente, a parte havia alegado em seu recurso especial (a) violação ao art. 535 do Código de Processo Civil de 1973 que, se reconhecida pelo Superior Tribunal de Justiça, acarretaria na anulação do acórdão recorrido; e (b) violação a outros dispositivos de lei federal que, se reconhecidas, levariam à reforma do acórdão recorrido. O recurso especial foi inadmitido pela Vice-Presidência do Tribunal de Justiça de São Paulo porque (a) não teria sido suficientemente demonstrada ofensa ao art. 535 do antigo Código de Processo Civil; e (b) para a análise das violações aos demais dispositivos de lei federal seria necessário o revolvimento do conjunto fático-probatório da demanda, atraindo a incidência da Súmula $7 /$ STJ. Diante desse cenário, no agravo em recurso especial o recorrente teria obrigatoriamente que impugnar ambos os fundamentos da decisão agravada? A impugnação apenas ao segundo fundamento (letra 'b') prejudicaria o conhecimento do agravo em recurso especial?

A jurisprudência do Superior Tribunal de Justiça era dissonante, tanto que os ERESp 831.326/SP foram desprovidos por maioria de votos. Havia julgados entendendo pela possibilidade de o recorrente questionar apenas um dos fundamentos autônomos da decisão agravada, posicionamento este que foi adotado no voto do Ministro João Otávio Noronha, e havia julgados no sentido oposto, exigindo que a parte se insurgisse contra todos os fundamentos da decisão de inadmissão do recurso especial, sob pena de não conhecimento do agravo. Esta última posição, verificável no voto do Ministro Luis Felipe Salomão, acabou prevalecendo.

Sem adentrar no mérito se o veredicto exarado no ERESp 831.326/SP foi acertado ou não, mas era imprescindível que houvesse uma harmonia na jurisprudência do Superior Tribunal de Justiça a respeito dessa controvérsia, que impacta um número imensurável de jurisdicionados. Qualquer pessoa que precisassem interpor agravos dirigidos aos tribunais superiores era afetada por essa discordância interna no Superior Tribunal de Justiça. Ora, o jurisdicionado deve ter o direito de saber o que precisa fazer quando da interposição do agravo em recurso especial ou extraordinário, se seria necessária a impugnação de todos os fundamentos da decisão agravada ou se bastaria manifestar inconformismo contra um dos fundamentos autônomos.

De acordo com as regras do atual Código de Processo Civil, no entanto, esses embargos de divergência não poderiam ser apreciados, porque a divergência versava sobre juízo 
de admissibilidade do recurso especial — a título de esclarecimentos, o ERESp 831.326/SP foi dirimido com base na legislação anterior.

Esse é apenas um exemplo de quão deletérios são os vetos dos incisos II e IV do art. 1.043 do Código de Processo Civil, promovidos pela Lei 13.256/2016, pois impedem a pacificação de questões críticas na jurisprudência dos tribunais superiores.

O Superior Tribunal de Justiça, na vigência do Código de Processo Civil de 1973, entendia que "os embargos de divergência são restritos aos julgamentos realizados no âmbito do recurso especial ou do recurso extraordinário", ${ }^{20}$ posição esta que foi refletida quando do julgamento dos embargos de divergência interpostos nos autos da ação rescisória 3.032/ PB para não conhecer o recurso. O Ministro Napoleão Nunes Maia Filho, no entanto, lavrou voto vencido admitindo os embargos de divergência, e lastreou seu veredicto em razões que valem ser mencionadas nesse trabalho.

No voto do Ministro, vale destaque ao seguinte trecho:

\begin{abstract}
Tendo em vista a função precípua e preponderante desta Corte Superior de Justiça, qual seja, a de uniformizar a jurisprudência pátria, de modo a remover antinomias entre julgamentos de questões ou teses submetidas à sua apreciação, mormente as de mérito, bem como a contribuir para a segurança jurídica, princípio tão consagrado pela moderna ciência do Direito e desejado pelos seus operadores, seria de se supor que o cabimento dos Embargos de Divergência, nesta Corte, pudesse se estender para abranger outros recursos ou ações em que se verificasse antagonismo de entendimentos sobre questão de direito, desimportando a sede em que ocorreram.
\end{abstract}

Logo, se o espírito dos embargos de divergência é uniformizar a jurisprudência pátria, um dos mecanismos concebidos pela lei para que isso venha a acontecer deve ser prestigiado pelo legislador, e não ter a sua abrangência restrita, como inadvertidamente o fez a Lei 13.256/2016. Os vetos da Lei 13.256/2016 aos incisos II e IV do art. 1.043 do Código de Processo Civil, portanto, são inoportunos, danosos ao jurisdicionados, e especialmente nocivos à diretriz veiculada no art. 926 do Código de Processo Civil, que norteia toda a aplicação da legislação. Os vetos vão de total encontro com o ideal de que os tribunais devem uniformizar sua jurisprudência e mantê-la estável, íntegra e coerente, e não deveriam ter ocorrido.

\title{
6. NOTAS
}

1. Art. 926. Os tribunais devem uniformizar sua jurisprudência e mantê-la estável, íntegra e coerente.

2. FERNANDES, Luis Eduardo Simardi. Capítulo I - Disposições Gerais Arts. 926 a 928. In: CRUZ E TUCCI, José Rogério; FERREIRA FILHO, Manoel Caetano; APRIGLIANO, Ricardo de Carvalho; DOTTI, Rogéria Fagundes; MARTINS, Sandro Gilbert (coord.). Código de Processo Civil Anotado. Rio de Janeiro: Editora GZ, 2018, p. 1334

3. CÂMARA, Alexandre Freitas. O Novo Processo Civil Brasileiro. 2. ed. São Paulo: Editora Atlas, 2016, p. 429.

4. GRECO FILHO, Vicente. Direito processual civil brasileiro. 18. ed. rev. e atual. São Paulo: Saraiva, 2007. v. 2 p. 389-390.

5. NERY, Nelson; ANDRADE NERY, Rosa Maria. Código de Processo Civil Comentado. 16. ed. São Paulo: Revista dos Tribunais, 2016, p. 1832.

6. DIDIER JR. Freddie, DA CUNHA, Leonardo Carneiro. Curso de Direito Processual Civil, Meios de 
Impugnação às Decisões e Processos nos Tribunais. v. 3, 13. ed. Salvador: Editora Podivm, 2016, p. 38.5

7. WAMBIER, Teresa Arruda Alvim, DANTAS, Bruno. Recurso Especial, Recurso Extraordinário e a Nova Função dos Tribunais Superiores no Direito Brasileiro. 3. ed. São Paulo: Revista dos Tribunais, 2016, p. 567.

8. WAMBIER, Teresa Arruda Alvim, DANTAS, Bruno. Recurso Especial, Recurso Extraordinário e a Nova Função dos Tribunais Superiores no Direito Brasileiro. 3. ed. São Paulo: Revista dos Tribunais, 2016, p. 570.

9. AgRg nos EAREsp 243.145/MG, Rel. Ministro Ari Pargendler, Rel. p/ Acórdão Ministra Nancy Andrighi, Corte Especial do Superior Tribunal de Justiça, julgado em 06/05/2015, DJe 24/06/2015.

\section{1. DAADMISSIBILIDADE DOS EMBARGOS DE DIVERGÊNCIA:}

1.1. A Corte Especial do STJ no julgamento do AgRg no EAREsp 243.145/MG, rel. Min. Ari Pargendler, relatora para o acórdão Min. Nancy Andrighi, Dje 24/06/2015, admitiu a oposição de embargos de divergência contra acórdão exarado em sede de agravo em recurso especial, quando a decisão, fundada no art. 544, $\S 4^{\circ}$, "c", do CPC, conhece do agravo para dar provimento ao recurso especial, ocasião em que estaria ocorrendo verdadeiro julgamento do mérito do apelo, não se admitindo naqueles casos em que o agravo é conhecido, mas nega-se seguimento ao recurso especial, já que em tais hipóteses não haveria ocorrido o enfrentamento do mérito da controvérsia, a ensejar a incidência da Súmula 315/STJ, segundo a qual "não cabem embargos de divergência no âmbito do agravo de instrumento que não admite recurso especial".

1.2. Em que pese o referido entendimento da Corte Especial do STJ, ele revela-se inaplicável ao presente casu, isto porque, em que pese no dispositivo da decisão monocrática mantida pelo acórdão embargado ter constado que foi negado provimento ao agravo em recurso especial manejado pela União, houve verdadeiro exame do mérito do recurso especial, oportunidade em que o acórdão embargado decidiu que são considerados ex-combatentes aqueles que, nos termos do art. $2^{\circ}$ da Lei $5.698 / 71$, realizaram pelo menos duas viagens em zonas de possíveis ataques de submarinos na condição de integrantes da Marinha Mercante, durante a Segunda Guerra Mundial, não tendo obstado o exame do mérito recursal em razão da ausência dos requisitos de admissibilidade do recurso, hipóteses estas que atrairiam a incidência da Súmula 315/STJ.

1.3. A Súmula 315/STJ aplica-se apenas naqueles casos em que os embargos de divergência busca o reexame de pressupostos de conhecimento do recurso especial, pois referido recurso tem por finalidade exclusiva a uniformização da jurisprudência interna do Tribunal quanto à interpretação do direito em tese, não servindo para discutir o acerto ou desacerto na aplicação de regra técnica de conhecimento de apelo nobre.

1.4. Naqueles casos em que o acórdão embargado obsta o recurso especial com base na Súmula 83/ STJ ("Não se conhece do recurso especial pela divergência, quando a orientação do tribunal se firmou no mesmo sentido da decisão recorrida"), para dizer que, no mérito, o acórdão impugnado estaria em sintonia com o entendimento firmado pelo STJ, não restam dúvidas de que houve exame do mérito da controvérsia recursal, não havendo razões para negar-se o direito da parte de interpor o competente embargos de divergência.

(EAREsp 200.299/PE, Rel. Ministro MAURO CAMPBELL MARQUES, Primeira Seção do Superior Tribunal de Justiça, julgado em 23/08/2017, DJe 01/09/2017)

11. ASSUNÇÃO NEVES, Daniel Amorim. Novo Código de Processo Civil Comentado. 3. ed. Salvador: Editora Podvm, 2018, p. 1.857.

12. $\S 1^{\circ}$ Poderão ser confrontadas teses jurídicas contidas em julgamentos de recursos e de ações de competência originária. 
13. "Ocorre, entretanto, que em algumas situações excepcionais deve ser admitido o recurso de embargos de divergência contra acórdão que não julgará propriamente um recurso especial, um recurso extraordinário ou um processo de competência originária, mas outro recurso interposto contra a decisão que julgar tais recursos."

ASSUNÇÃO NEVES, Daniel Amorim. Novo Código de Processo Civil Comentado. 3. ed. Salvador: Editora Podvm, 2018, p. 1.858 - grifou-se

"Recurso e ação originária. Exatamente nesta linha, e pelas mesmas razões, redigiu-se o IV do art. 1.043, que deixava claro que também a divergência ocorrida entre acórdão que julga recurso e a ação de competência originária do Tribunal enseja embargos de divergência. Este inc. IV foi revogado pela Lei 13.256/2016, mas a regra de que não importava o 'veículo' (ação ou recurso), mas a desarmonia de pensamento existente entre os membros do Tribunal Superior, fica mantida pelo $\S^{\circ}$, que não foi revogado, que diz: podem ser confrontados acórdãos que julgam ações com acórdãos que julgam recursos."

(WAMBIER, Teresa Arruda Alvim; CONCEIÇÃO, Maria Lúcia Lins; RIBEIRO, Leonardo Ferres da Silva; TORRES DE MELLO, Rogério Licastro. Primeiros Comentários ao Novo Código de Processo Civil. 2. ed. São Paulo: Revista dos Tribunais, 2016. p. 1.696 - grifos no original)

14. "Embora, nesse ponto, equiparem-se ao que se previa, no CPC/73, o modelo adotado na versão original da nova lei processual era amplíssimo, já que os embargos de divergência seriam cabíveis não só contra decisões proferidas em recurso especial ou extraordinário divergentes de decisões proferidas por outros órgãos colegiados, mas, também, contra decisões proferidas em processos de competência originária. Com a reforma da Lei 13.256, tais embargos passaram a se restringir a controvérsias sobre o mérito (mesmo no caso previsto no inciso II do art. 1.043 do CPC/2015, embora não se tenha admitido o recurso, haverá que ser decidido o mérito).

\section{$[\ldots]$}

Revogado pela Lei 13.256/2016, o inciso IV do art. 1.043 do CPC/2015 admitia a interposição do recurso também contra acórdão de órgão fracionário que, 'nos processos de competência originária', divergia do 'julgamento de qualquer outro órgão no mesmo tribunal'. Nesse contexto, à luz das hipóteses de cabimento (mais restritas) dos embargos de divergência tal como resultou a redação ao art. 1.043 do CPC/2015 após a reforma da Lei 13.256/2016, tende a manter-se a orientação no sentido de que é 'requisito para a interposição de embargos de divergência que os acórdãos trazidos a confronto tenham sido proferidas em sede de recurso especial, não se prestando para tanto julgados exarados em recurso em mandado de segurança, recurso ordinário, conflito de competência, ação rescisória, ação penal e em agravo regimental em agravo, no último caso, quando desprovido, pois, nessa hipótese, não se adentra no mérito do recurso especial' (STJ, AgRg nos ERESp 1168353/RS, j. 20/05/2015. Rel. Min. João Otávio Noronha, Corte Especial)."”

(MEDINA, José Miguel Garcia. Novo Código de Processo Civil Comentado. 4. ed. São Paulo: Revista dos Tribunais, 2016. p. 1.582/1.583)

15. AgInt nos EAREsp 467.315/SP, Rel. Ministro Mauro Campbell Marques, Corte Especial, julgado em 13/08/2019, DJe 16/08/2019.

16. 2. Mérito/mérito - admissibilidade/admissibilidade. Os incs. I e II nada mais fazem di qye descrever as hipóteses clássicas de cabimento de embargos de divergência. $O$ acórdão de órgão fracionário - turma ou seção - adota tese jurídica diferente da que adotou qualquer outro órgão do mesmo tribunal, inclusive o pleno, sendo ambos: acórdão embargado e divergente, sendo, ambos relativos ao juízo do mérito (I). $2.2 \mathrm{~A}$ nova regra revogou o in. II, mas manteve o $\S 2^{\circ}$. Teria a norma do inc. Il desaparecido? A nosso ver, não. O inciso revogado admitia expressamente que se interpusessem embargos de divergência quando esta se revelasse no juízo de admissibilidade. Mas além de não existir dispositivo que proíba o uso do recurso nesta hipótese, esta possibilidade é, ainda, reforçada pelo $\S 2^{\circ}$, que não foi revogado: divergências de direito material e de direito processual autorizam o recurso!" 
WAMBIER, Teresa Arruda Alvim, CONCEIÇÃO, Maria Lúcia Lins, RIBEIRO, Leonardo Ferres da Silva, MELLO, Rogério Licastro Torres de. Primeiros Comentários ao Novo Código de Processo Civil. 2. ed. São Paulo: Revista dos Tribunais, 2016. p. 1.695/1.696 - grifos no original

17. Art. $6^{\circ} \mathrm{A}$ decretação da falência ou o deferimento do processamento da recuperação judicial suspende o curso da prescrição e de todas as ações e execuções em face do devedor, inclusive aquelas dos credores particulares do sócio solidário.

$\S 4^{\circ} \mathrm{Na}$ recuperação judicial, a suspensão de que trata o caput deste artigo em hipótese nenhuma excederá o prazo improrrogável de 180 (cento e oitenta) dias contado do deferimento do processamento da recuperação, restabelecendo-se, após o decurso do prazo, o direito dos credores de iniciar ou continuar suas ações e execuções, independentemente de pronunciamento judicial.

18. "A admissibilidade dos recursos excepcionais é matéria com sede na Constituição (CF 102, III e 105, III), de sorte que não pode se subtrair do STJ e do STJ a oportunidade de uniformizar o seu entendimento quanto a esse tema. Ademais, deve se seguir-se o comando do CPC 926 caput, no sentido de que os tribunais devem manter sua jurisprudência estável, coerente e íntegra, e o dissenso, ainda que recaia sobre a admissibilidade do RE e/ou RESp, é circunstância que conspira contra a estabilidade, integridade e coerência da jurisprudência do STF e/ou STJ"

NERY, Nelson; ANDRADE NERY, Rosa Maria. Código de Processo Civil Comentado. 16. ed. São Paulo: Revista dos Tribunais, 2016. p. 2.396

19. PROCESSO CIVIL. EMBARGOS DE DIVERGÊNCIA. IMPUGNAÇÃO ESPECÍFICA DE TODOS OS FUNDAMENTOS DA DECISÃO RECORRIDA. ART. 544, § 4 I, DO CPC/1973. ENTENDIMENTO RENOVADO PELO NOVO CPC, ART. 932.

1. No tocante à admissibilidade recursal, é possível ao recorrente a eleição dos fundamentos objeto de sua insurgência, nos termos do art. 514, II, c/c o art. 505 do CPC/1973. Tal premissa, contudo, deve ser afastada quando houver expressa e específica disposição legal em sentido contrário, tal como ocorria quanto ao agravo contra decisão denegatória de admissibilidade do recurso especial, tendo em vista o mandamento insculpido no art. 544, $\S 4^{\circ}$, I, do CPC, no sentido de que pode o relator "não conhecer do agravo manifestamente inadmissível ou que não tenha atacado especificamente os fundamentos da decisão agravada" - o que foi reiterado pelo novel CPC, em seu art. 932.

2. A decisão que não admite o recurso especial tem como escopo exclusivo a apreciação dos pressupostos de admissibilidade recursal. Seu dispositivo é único, ainda quando a fundamentação permita concluir pela presença de uma ou de várias causas impeditivas do julgamento do mérito recursal, uma vez que registra, de forma unívoca, apenas a inadmissão do recurso. Não há, pois, capítulos autônomos nesta decisão.

3. A decomposição do provimento judicial em unidades autônomas tem como parâmetro inafastável a sua parte dispositiva, e não a fundamentação como um elemento autônomo em si mesmo, ressoando inequívoco, portanto, que a decisão agravada é incindível e, assim, deve ser impugnada em sua integralidade, nos exatos termos das disposições legais e regimentais.

4. Outrossim, conquanto não seja questão debatida nos autos, cumpre registrar que o posicionamento ora perfilhado encontra exceção na hipótese prevista no art. 1.042, caput, do CPC/2015, que veda o cabimento do agravo contra decisão do Tribunal a quo que inadmitir o recurso especial, com base na aplicação do entendimento consagrado no julgamento de recurso repetitivo, quando então será cabível apenas o agravo interno na Corte de origem, nos termos do art. $1.030, \S 2^{\circ}$, do CPC.

5. Embargos de divergência não providos. ERESp 831.326/SP, Rel. Min. Luis Felipe Salomão, Corte Especial do Superior Tribunal de Justiça, julg. 19.09.18

20. EDv na AÇÃO RESCISÓRIA No 3.032 - PB, Rel. p/ Acórdão Ministro Ari Pargendler, Corte Especial do STJ, julg. 21.11.12 


\section{REFERENNCIAS}

ASSUNÇÃO NEVES, Daniel Amorim. Novo Código de Processo Civil Comentado. 3. ed. Salvador: Editora Podvm, 2018.

BRASIL. Superior Tribunal de Justiça. AgRg nos EAREsp 243.145/MG. Relator: Min. Ari Pargendler, 6 maio 2015. Relator p/ Acórdão: Ministra Nancy Andrighi. Diário da Justiça Eletrônico: Corte Especial, Brasília, DF, 24 jun. 2015.

BRASIL. Superior Tribunal de Justiça. AgRg nos EAREsp 376.403/PI. Relator: Min. Gurgel de Faria, 9 dez. 2015. Diário da Justiça Eletrônico: Terceira Seção, Brasília, DF, 1 fev. 2016.

BRASIL. Superior Tribunal de Justiça. AgInt nos EAREsp 467.315/SP. Relator: Min. Mauro Campbell Marques, 13 ago. 2019. Diário da Justiça Eletrônico: Corte especial, Brasília, DF, 16 ago. 2019.

BRASIL. Superior Tribunal de Justiça. EAREsp 200.299/PE. Relator: Min. Mauro Campbell Marques, 23 de agosto de 2017. Diário da Justiça Eletrônico: Primeira Seção, Brasília, DF, 01 set. 2017.

BRASIL. Superior Tribunal de Justiça. EDv na AÇÃO RESCISÓRIA No 3.032 - PB. Acórdão. Relator: Min. Ari Pargendler, 21 de novembro de 2012. Corte Especial do Superior Tribunal de Justiça. Brasília: STF, 2012.

BRASIL. Superior Tribunal de Justiça. ERESp 831.326/SP. Relator: Min. Luis Felipe Salomão, 19 de setembro de 2018. Corte Especial do Superior Tribunal de Justiça. Brasília: STF, 2018.

BRASIL. Superior Tribunal de Justiça. Súmula $n^{\circ} 315$. Não cabem embargos de divergência no âmbito do agravo de instrumento que não admite recurso especial. Diário da Justiça: Corte Especial, Brasília, DF, p. 102, 18 out. 2005.

CÂMARA, Alexandre Freitas. O Novo Processo Civil Brasileiro. 2. ed. São Paulo: Editora Atlas, 2016.

DIDIER JR. Freddie; DA CUNHA, Leonardo Carneiro. Curso de Direito Processual Civil, Meios de Impugnação às Decisões e Processos nos Tribunais. v. 3, 13. ed. Salvador: Editora Podivm, 2016.

FERNANDES, Luis Eduardo Simardi. Arts. 926 a 928. In: CRUZ E TUCCI, José Rogério; FERREIRA FILHO, Manoel Caetano; APRIGLIANO, Ricardo de Carvalho; DOTTI, Rogéria Fagundes; MARTINS, Sandro Gilbert (coord.). Código de Processo Civil Anotado. Rio de Janeiro: Editora GZ, 2018, livro III, título I, cap. I, p. 1449-1455.

GRECO FILHO, Vicente. Direito Processual Civil Brasileiro. 18. ed. rev. e atual. São Paulo: Saraiva, 2007.

MARINONI, Luiz Guilherme; ARENHART, Sérgio Cruz; MITIDIERO, Daniel. Código de Processo Civil Comentado. 4. ed. São Paulo: Revista dos Tribunais, 2018.

MEDINA, José Miguel Garcia. Novo Código de Processo Civil Comentado. 4. ed. São Paulo: Revista dos Tribunais, 2016.

NERY, Nelson; ANDRADE NERY, Rosa Maria. Código de Processo Civil Comentado. 16. ed. São Paulo: Revista dos Tribunais, 2016. 
WAMBIER, Teresa Arruda Alvim; CONCEIÇÃO, Maria Lúcia Lins; RIBEIRO, Leonardo Ferres da Silva; MELLO, Rogério Licastro Torres de. Primeiros Comentários ao Novo Código de Processo Civil. 2. ed. São Paulo: Revista dos Tribunais, 2016.

WAMBIER, Teresa Arruda Alvim; DANTAS, Bruno. Recurso Especial, Recurso Extraordinário e a Nova Função dos Tribunais Superiores no Direito Brasileiro. 3. ed. São Paulo: Revista dos Tribunais, 2016.

Recebido em: 05/08/2020

Aceito em: 21/08/2020 